\title{
Leadership Succession and the High Drama of Political Conduct: Corruption Stories from Samoa
}

\author{
Jack Corbett \\ Roannie Ng Shiu
}

\begin{abstract}
Politicians in the Pacific Islands are regularly accused of corruption and yet, paradoxically, they also tend to be the most vocal public commentators when incidents of misconduct arise, with accusation and counter-accusation all part of the political theatre. Given their central role in these debates, we ask how politicians interpret political conduct. Based on interviews and public comments, we explore the meanings and beliefs that politicians in Samoa ascribe to three interrelated cases where the actions of their colleagues are under scrutiny. We find a series of divergent and conflicting views. We add to the literature on corruption, both in the Pacific and more generally, by showing how questions about conduct not only vary according to context but are invariably rooted in the cut and thrust of everyday politics, which in this case is dominated by the question of leadership succession.
\end{abstract}

KEYWORDS: political conduct, leadership, corruption, Samoa, Pacific Islands, small island states

DOI: http:/ /dx.doi.org/10.5509/2014873743

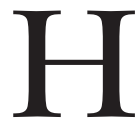

ow leaders should behave, and the best ways to ensure standards of conduct are upheld, are important questions for all polities but they have become the subject of growing interest in the Pacific Islands due to public concern with corruption. Politicians in particular are regularly

JACK Corbetr is a research fellow at the Centre for Governance and Public Policy and the Griffith Asia Institute at Griffith University and a visiting fellow at the School of International, Political and Strategic Studies at The Australian National University. Being Political: Leadership and Democracy in the Pacific Islands is forthcoming in 2015 with the University of Hawaii Press.

RoAnnie Ng SHIU is a Pasifika Outreach and Research Fellow at the School of International, Political and Strategic Studies at The Australian National University

Acknowledgements: We would like to thank Peter Larmour for his help with the literature on corruption, and Kerryn Baker and the journal's editors and anonymous reviewers for their comments on an earlier version of this article. Any errors are, of course, our own.

1 Peter Larmour, Interpreting Corruption: Culture and Politics in the Pacific Islands (Honolulu: University of Hawaii Press, 2012). 
accused of misconduct with the populist narrative, driven by local actors as well as international donors, tending to take a populist stance: sympathizing with the "good" people against the "bad" politicians. ${ }^{1}$ Thus one of Samoa's leading literary figures, Albert Wendt, observed that:

I have watched the euphoria of independence throughout the Pacific degenerate after ten years into political corruption ... Our new leadership, our new elite-of which I am a member, I am sorry to sayis carrying out a form of colonialism which may even be worse than what we got rid of. ${ }^{2}$

Politicians, in this view, are self-interested, power hungry and out of touch with the views and needs of ordinary people.

Characterizing public debate about political conduct as an "us against them" contest is, however, misleading. The adversarial nature of democratic politics means that politicians regularly accuse each other of misconduct, just as opposition politicians invariably argue that the government is out of touch with the views and needs of ordinary people. Indeed, paradoxically, when it comes to misconduct and corruption, politicians tend to be the most vocal protagonists, with accusation and counter-accusation all part of the "high drama" of political theatre. As we shall see, this is particularly pertinent when set against the backdrop of leadership succession. From a populist perspective, however, this messy, often petty and rarely uplifting public debate tends to be dismissed as rhetoric; the empty words of leaders seeking to justify their own positions and secure maximum advantage. Commentators may sympathize with one side over the other but, for the most part, see the sum total of this public outpouring as further proof that politicians are at best hypocritical and at worst outright liars.

The literature on political conduct and corruption is voluminous in its disciplinary breadth and geographic scope, but for the most part it supports this view of politicians as corrupted, particularly in countries where democracy is synonymous with "vote buying" and other activities often subsumed under the label "clientelism." ${ }^{3}$ Typically, scholars adopt a "use of public office for private gain" definition of corruption and either a rational-actor or institutionalist approach in their analysis of it. ${ }^{4}$ More recently, there has been

2 Albert Wendt cited in Vilsoni Hereniko, "Clowning as Political Commentary: Polynesia, Then and Now," The Contemporary Pacific 6, no. 1 (1994): 3.

3 Allen Hicken, "Clientelism," Annual Review of Political Science 14 (2011): 289-310; William Callahan, "The Discourse of Vote Buying and Political Reform in Thailand," Pacific Affairs 78, no. 1 (2005): 95-113.

For review see David Jancsics, "Interdisciplinary Perspectives on Corruption," Sociological Compass 8, no. 4 (2014): 358-372. For institutionalists, the classic anti-corruption strategy involves building stronger official capacity that can curb the excess of venal leaders. See for example Bo Rothstein, "Trust, Social dilemmas, and Collective Memories: On the Rise and Decline of the Swedish Model," Journal of Theoretical Politics 12, no. 4 (2000): 477-501. 
a call for scholars to broaden how they define corruption and to be more dynamic in the ways they conduct research on it. ${ }^{5}$ This article situates its contribution in relation to this latter literature. Following Mark Philp, we see definitions of corruption as hinging on socially constructed meanings and beliefs about what constitutes both ideal and perverse conduct. ${ }^{6}$ That is, standards are not fixed but are constantly (re)negotiated, and that any such negotiation is implicitly a political process.

This article aims to understand how politicians see and interpret corruption and misconduct in office. Given that they are invariably at the centre of misconduct allegations-as either the accuser or the accused-we believe that their reflections are too important to ignore. By paying close attention to what politicians say-how they define the problem, and how they perceive the solution, and, inversely, what they consider to be exemplary behaviour-we provide an alternative view of political conduct to that commonly found in popular talk, media and donor manifestos. Drawing on public documents and interviews with politicians and journalists, we provide a "thick description" of three interrelated case studies where politicians have recently been accused of misconduct in Samoa, and use these to draw out lessons of general relevance to students of politics and political leadership in the Pacific, other small island states, and elsewhere.

There is a small but growing literature on political leadership, conduct and corruption in the Pacific but for the most part it does not focus explicitly on the views and experiences of politicians. ${ }^{7}$ Rather, scholars typically grapple with the apparent disjuncture between modern liberal democratic values, synonymous with the separation of "public" and "private," and the prevailing cultures of small island Pacific states where "everybody knows everybody." In his recent book on corruption, Peter Larmour delineates between "gothic" (meaning grim and gloomy) and cultural relativist (actions and practices have different meanings according to context) definitions, with the former associated with donors and non-government organizations like Transparency International. ${ }^{9}$ Building on this, Grant Walton's work on

\footnotetext{
Grant Walton, "Is all corruption dysfunctional? Perceptions of corruption and its consequences in Papua New Guinea," Public Administration and Development 33, no. 3 (2013): 175-190; Jancsics, "Interdisciplinary Perspectives on Corruption."

6 Mark Philp, "Defining Political Corruption,” Political Studies XLV (1998): 436-462; see also Philp, Political Conduct (Cambridge, Massachusetts, and London, England: Harvard University Press, 2007), 1 .

Larmour, Interpreting Corruption; Walton, "Is all corruption dysfunctional?" 175-190.

Cluny Machpherson and La'avasa Macpherson, "Where theory Meets Practice: the limits of the Good Governance Program," in Governance in Samoa: Pulega i Samoa, eds. Elise Huffer and Asofou So'o (Canberra and Suva: Asia Pacific Press and IPS Publications), 2000, 17-40; Jack Corbett, "'Everybody Knows Everybody': Practising Politics in the Pacific Islands," Democratization ahead of print (2013): DOI:10.1080/13510347.2013.811233.
} 
popular understandings of corruption in Papua New Guinea, for example, emphasizes different interpretations within the "gothic" view that, in addition to the conventional "public office for private gain" definition, includes an interpretation of corruption as "individual" decay. ${ }^{10}$ As we shall see, this latter perspective is particularly important for how we understand the cases discussed here.

This article adds to this discussion by linking the views of individual politicians about what constitutes corruption with specific instances where they or their colleagues face public scrutiny about their conduct. Specifically, all three cases are set against the backdrop of ongoing debate about who will be the next leader of the Human Rights Protection Party (HRPP). The "high drama" of leadership succession is common to all democracies but it is particularly significant in Samoa, where the HRPP has held government for 30 years. In doing so we show that meanings not only diverge, in the way that Walton describes, but that they interact in an iterative and dramatic fashion with the political context in which they are set. However, we do not see this context, be it institutional or discursive, as deterministic or path dependent but rather as contingent and relational. In these three cases, discourses or narratives about corruption (like "democracy" or "culture") become rhetorical weapons employed by political elites jockeying for position and advantage. So, we add to the literature on the divergent meanings of corruption by providing an agent-centred account of a leadership struggle. Invariably, this process of self-regulation is as messy, petty and off-putting as the staunchest critics of democratic politics claim. ${ }^{11}$ However, our intent here is not to cast normative judgements about the desirability of this process, nor to provide possible solutions. Rather, our more modest and fundamental aim is to understand how politicians make sense of these instances and act within them.

In line with our aims-to understand how political actors see and experience political conduct -we derive our methodological approach from the interpretivist tradition. The central precepts of interpretive research have been extensively canvassed elsewhere and so we will not rehash them here. ${ }^{12}$ In summary, interpretive research is typically based on constructivistsubjectivist rather than realist-objectivist propositions. ${ }^{13}$ The aim is to

10 Walton, "Is all corruption dysfunctional? Perceptions of corruption and its consequences in Papua New Guinea"; Walton, "Defining Corruption where the State is Weak: The Case of Papua New Guinea," The Journal of Development Studies ahead-of-print (2014): DOI: 10.1080/00220388.2014.925541.

11 Corbett, "Politicians and Professionalization in the Pacific Islands: Revisiting Self-Regulation?" Politics Eै Policy 41, no. 6 (2013): 852-876.

12 For example see Mark Bevir and Rod Rhodes, Governance Stories (London and New York: Rutledge, 2006).

13 Critical realists, many of whom use similar methods and ask similar questions, despite retaining a commitment to a realist ontology, are an important exception. For discussion see David Marsh, "Keeping ideas in their place: in praise of thin constructivism," Australian Journal of Political Science 44 , no. 4 (2009): 679-696. 
understand the "webs of significance," generated by uncovering the meanings and beliefs that inform human actions, within which political actors live their lives. ${ }^{14}$ The assumption is that people have reasons for their actions, conscious and unconscious, and that a key task for scholars of politics is to uncover what these reasons are. In relation to this article, the key concept we employ from the interpretive cannon is "situated-agency," which refers to the capacity of individuals to reflect on their own beliefs and act for their own reasons, albeit the meanings and beliefs that inform their actions are embedded within a particular context or background of inherited traditions: humans can be innovative,but they are not autonomous. ${ }^{15}$ By focusing on three cases set against the backdrop of questions about leadership succession, we uncover the individual beliefs of actors and situate them in the context of prevailing traditions that frame how corruption is understood.

Our analysis draws on two main sources. The first is the public record and newspaper commentary in particular. The second are interviews with Samoan politicians which were conducted in two phases. The first 16 were conducted in early 2011 as part of a larger book-length project on politicians in the Pacific Islands. ${ }^{16}$ They included general discussion about corruptionwhat it was, how and why it occurs-but were not restricted to this topic. The second 11 were undertaken in late 2013. Again, the majority were conducted with politicians but we also sought the views of two prominent journalists. These latter interviews were specifically focused on the three case studies that we discuss here and as such form the core of our empirical material. Interviews were granted on our explicit commitment not to include names in any publications. There are a number of reasons for this. Obviously, given the nature of the topic, we hoped that de-identifying respondents would allow them to speak more freely. However, given that the events we are discussing are ongoing, we also wanted to protect our informants. Importantly, our aim is not to reach a verdict on any of the cases we discuss here - we are not the judge, jury or executioner - but instead to highlight the way discussions about conduct take place and draw lessons of more general relevance to theorists and policy makers. We acknowledge that the views of politicians represent only one side of an inherently complex story, but nevertheless believe these views are important given their prominence and growing concern with misconduct. In cases where respondent comments could be considered defamatory we have generally preferred to use quotes from the published record. In all instances where we have used quotes from interviews to illustrate a point they could have been substituted for several others.

14 Clifford Geertz, The Interpretation of Cultures: Selected Essays (New York: Basic Books, 1973).

15 Bevir and Rhodes, "Author's Response: Politics as Cultural Practice," Political Studies Review 6 (2008): 171, 174 .

16 Jack Corbett, Being Political: Leadership and Democracy in the Pacific Islands (Honolulu: University of Hawaii Press), forthcoming. 


\section{The Context}

Independent from New Zealand since 1962, Samoa has a parliamentary democracy along Westminster lines with a single 49-member chamber. The head of state convenes parliament and appoints the member who enjoys the confidence of the majority as the head of government. The framers of Samoa's constitution anticipated that political parties would emerge on the floor of parliament but for the first 17 years after independence they were conspicuous by their absence. This changed with the founding of the HRPP in 1982 but, following Westminster conventions, term limits are not stipulated in the constitution and so recent prime ministers have enjoyed long tenures in office. Samoa does not have an anti-corruption commissioner but ranks as "Free" in the annual Freedom House democracy rankings. The press is also considered "Free" (the Samoa Observer is colloquially seen as a more vocal critic of the HRPP government than the Opposition). A full discussion of Samoa's political history, including how contemporary institutions interact with pre-colonial political systems (conventionally known as the fa'amatai) is beyond our scope here ${ }^{17}$ More recent political machinations are, however, of direct relevance as the three cases we discuss occur against the backdrop of an increasingly complex political environment in which the question of leadership succession is paramount but, in line with Westminster conventions, the mechanisms for transitioning from one leader to the next remain opaque in practice.

For the last 30 years Samoa has been governed under successive prime ministers by the HRPP, who have been the predominant force in Samoan politics. ${ }^{18}$ Opposition parties have come and gone (Samoa Democratic United Party, for example) but have never been able to secure more than a handful of seats. The stability brought by the HRPP sits in contrast to most other democracies in the Pacific region, which have experienced persistent executive instability. As a result, Samoa is often held up as a paragon of constancy by donors in particular. Conversely, amongst overseas Samoan communities, and Apia-based elites in particular, there has been growing concern with political conduct and corruption. ${ }^{19}$ This culminated in 1998 with the assassination of then minister of Public Works, Luagalau Levaula

17 For example see Elise Huffer and Asofou So'o, eds., Governance in Samoa: Pulega $i$ Samoa (Canberra and Suva: Asia Pacific Press and IPS Publications); Asofou So'o, Democracy and Custom in Samoa (Suva, Fiji: IPS Publications, 1998); Asofou So'o and Jon Fraenkel, "The role of ballot chiefs (matai palota) and political parties in Samoa's shift to universal suffrage," Commonwealth and Comparative Politics 43, no. 3 (2005): 333-361; Morgan Tuimaleali'ifano, "'Aia Tatau and Afioga Tutasi: 'Aiga versus Tama a 'Aida. Manipulation of Old and New Practices: An MP for Falelatai and Samatau in Samoa's 2001 Elections," Journal of Pacific History 36, no. 3 (2001): 317-325; Stephanie Lawson, Tradition versus Democracy in the South Pacific (Cambridge: Cambridge University Press, 1996).

18 Iati Iati, "Samoa's Price for 25 Years of Political Stability," The Journal of Pacific History 48, no. 4 (2013): 443-463.

Iati, "Samoa's Price for 25 Years of Political Stability." 
Kamu, by Eletise Leafa Vitale, who was the son of Leafa Vitale, a HRPP member of parliament (MP) and the previous minister of Public Works, amidst widespread corruption allegations. ${ }^{20}$

As we shall see in all three cases, the lead-up to the 2016 election is shaping up as a watershed moment for the HRPP. In the 2011 elections the party won another resounding victory that delivered office to the incumbent prime minister, Tuilaepa Aiono Sailele Malielegaoi, who first entered parliament in 1981. In popular "talk," confirmed in our interviews, it was commonly believed that this would be his last term as prime minister. He will turn 71 in 2016 and planned to step down. As a result, there was considerable manoeuvring before and after the 2011 elections by those HRPP members who saw themselves as potential successors. Over the journey, there have been two constant figures in Tuilaepa's cabinets, Misa Telefoni Retzlaff and Fiame Naomi Mataafa; however, Misa retired prior to the 2011 election whilst it has never been entirely clear whether Fiame wanted the top job or, given that she is one of only two women parliamentarians, whether she could secure the necessary support even if she did. In this vacuum, several candidates put themselves forward-most politicians do not lack ambition and interviewees joked that there were 49 potential prime ministers in parliament-but two in particular were seen to be front-runners: the deputy prime minister, Fonotoe Nuafesili Pierre Lauofo, and the minister of Finance, Faumuina Tiatia Liuga. Both figures are particularly important to this article as they are the subject of our first two cases. Aside from the prime minister, Fonotoe was the only member to be elected unopposed at the 2011 election. He used this time to garner support amongst his colleagues and as a result was made deputy prime minister in only his second term in office-he was not in the 2006-2011 cabinet. Faumuina has been a cabinet minister since he entered parliament in 2001. In 2011 he was made minister of Finance.

\section{Case study 1: Misuse of Funds}

Our first case is the most high profile, and in many ways the most conventional as it relates to the misappropriation of public funds, and yet in the context of Samoa and the HRPP the case is anything but straightforward. On 3 May 2013, 19 members of the HRPP wrote a letter to the prime minister, later published in the Samoa Observer newspaper, outlining a series of misgivings about Faumuina's conduct. ${ }^{21}$ Grievances included: the mishandling of infrastructure projects, including the bungled construction of several markets; extravagant use of funds on his personal office and car; defeat in the government's court case against the company Siva Afi; and various failures to adhere to proper process. As outlined, Faumuina is a long-serving HRPP

20 Iati, "Samoa's Price for 25 Years of Political Stability,", 459.

21 Editor, "HRPP "has collapsed”?" Samoa Observer, 19 May 2013. 
minister and has been touted as a possible successor to Tuilaepa. Dissension of this type in a party that has been in power for almost thirty years is virtually unprecedented. When it published the letter, the Samoa Observer ran with the headline "HRPP 'has collapsed'?" 22 And, for much of May 2013, the collapse of the party seemed a distinct possibility. To date, this scenario has not eventuated but the discussion and manoeuvring around the incident reveals the ways norms and conventions about political conduct are negotiated in Samoa.

Whether Faumuina broke the law remains a matter of intense discussion. In a press release responding to his critics he claimed that moves to remove him were based on "political opportunism." We will return to this later but for now the important point is that a significant proportion of MPs within Faumuina's own party wanted him sacked:

[It's] incompetence ... I mean, they are doing things because they know it's not their money. They know very well the investment is not a good investment because it involves a substantial amount of capital ... So he keeps on spending money like as if-well, it's not really his money... if that was your money would you go ahead and build all this knowing that you failed from one and then you plan for another one, failed again, and you are still doing it? ... So, and now he's spending public funds extravagantly and he never contributed a cent to the economy ... [He] refurbish [ed] his office, spending $\$ 600,000$ tala, and yet farmers were crying out for a shelter. [HRPP MP] ${ }^{23}$

A number of issues are bound up in the explanation of why Faumuina is not fit to hold his portfolio. The first relates to policy: MPs believe he has made poor choices that have adversely affected the lives of Samoan citizens. The misconduct here relates to mismanagement rather than misappropriation of public funds. Indeed, as the above extract illustrates, some MPs would prefer that Faumuina spent public funds like he would his own-presumably more judiciously—rather than continue his current extravagance. As we shall see in the other two cases, culture is often touted as one reason why actions and practices considered corrupt elsewhere are deemed appropriate in a Pacific context; this is what Larmour calls a relativist view of corruption. But, here the relativism is also economic and supports Walton's view that in the Pacific, political and bureaucratic extravagance is often considered corrupt $\mathrm{t}^{24}$ :

We depend on aid ... unless we get funds or loans, then we will not be able to embark on those other projects ... If we can't use these public funds properly and yet all the ministers are crying out for more funds, then how are we going to operate in the future, given that once we

22 Editor, "HRPP "has collapsed"?” Samoa Observer, 19 May 2013.

23 Author interview, Apia, Samoa, 6 November 2013.

24 Walton, "Defining Corruption where the State is Weak: The Case of Papua New Guinea," 6. 
promote, we are not sure of any more assistance from the government? Maybe we would still get assistance, but at higher interest rates or something like that. No more concessions. [HRPP MP $]^{25}$

Irresponsible expenditure can also damage Samoa's reputation internationally which, aside from the potential consequences for aid flows that the above extract highlights, prickles national pride. However, taken together, the two extracts illustrate that many see Faumuina's main failing as his willingness to sustain a rich country's tastes on a poor country's budget. This is why the decision to upgrade his office and purchase an expensive vehicle is considered especially grievous; it indicates a degree of selfishness which, in a context where communal service is prized, is virtually unforgiveable. Moreover, given that he was a UNDP employee, and had thus not paid tax in Samoa, he is seen as not contributing to community life. Accordingly, selfishness also featured in the letter sent by HRPP members of parliament (MP) to the prime minister complaining about Faumuina's conduct. Underpinning this critique is a prevailing culture of service and reciprocity, both of which are highly prized in Samoa. Samoans are often judged against their service to their aiga (extended family), their village and to a lesser extent, Samoa more broadly when seeking a matai or chiefly title. ${ }^{26}$

Popular anxiety about politicians entering public office to serve private interests rather than pursue public goods is an age-old concern. The misconduct here relates to character:

[He's] like a high-minded person. He thinks he knows all ... He doesn't talk thousands ... He now talks billions, so we call him a nickname; Mr. Billion. The first time he became minister, he was telling the world, I mean telling us, he was involved with projects worth billions when he was with UNDP. We found out he was not really involved in any project discussion ... He [only] thinks of himself. [HRPP MP $]^{27}$

The last line infers self-interest but the initial accusation regards hubris. Faumuina, his colleagues are saying, is not a humble man. He sees himself as better than his fellow MPs and has a sense of entitlement, in part due to an inflated view of his previous job, that many feel is unwarranted. From here, having interrogated his character and found it wanting, it is not hard to see why some MPs feel that in this case incompetence masks more sinister self-interest; a number of our interviewees conceded that they were fairly

25 Author interview, Apia, Samoa, 6 November 2013.

26 The term matai has a complex history but is commonly employed to denote the head of a family or clan. For discussion see Serge Tcherkezoff, "Are the matai 'out of time'? Tradition and democracy: contemporary ambiguities and historical transformations of the concept of chief," in Governance in Samoa: Pulega i Samoa, eds. Elise Huffer and Asofou So'o (Canberra and Suva: Asia Pacific Press and IPS Publications), 113-132.

27 Author interview, Apia, Samoa, 6 November 2013. 
confident that, based on his decisions, somebody, possibly including Faumuina, was lining their pockets at the public's expense.

But where are the checks and balances in all of this? How is it that a minister could make these policy decisions without anybody questioning what he was up to? Does this case really illustrate a failing of one man's character or are we witnessing a failure of proper process? The tabling in late December 2013 of a report by the Officers of Parliament Committee, whose membership includes both government and opposition MPs, into government administration, indicates a process at work. ${ }^{28}$ And yet, the report highlights several failings of process, particularly in regards to the administration of government corporations, like the Samoa Land Corporation, which purchased Faumuina's car and paid for his office refurbishments, and calls for legal measures to deal with corrupt practices.

In a Westminster system cabinet is the peak body where decisions are made and, by convention, is subject to collective responsibility. Such conventions persist in Samoa and have a direct bearing on this case as, in a number of instances, Faumuina stands accused of making decisions without cabinet's approval, or, in the case of cost variations, of not re-seeking agreement. MPs were divided about the appropriateness of these actions. In the case of his office refurbishment and his car, was he required to seek cabinet's permission, and, regardless of his legislated powers, should he have done so anyway? The issue here is the degree of discretion ministers have over their portfolio responsibilities. There are no easy answers and MPs hold divergent views.

Two important questions emerge from concerns about the abuse of process: what entitlement and privileges should ministers receive and how should disputes about their conduct in office be resolved? Questions about MP entitlements are always newsworthy but the roots of these concerns are much deeper. Ministers who claim not to have substantial economic or financial affiliations outside of politics say that they are less corruptible. Conversely, echoing Max Weber's famous distinction between those who live "for" and "off" politics, ${ }^{29}$ those who have other means say they are less reliant on their political income and therefore are not corrupted by the need to be re-elected; the assumption here is that the rich are above corruption. In Samoa, getting elected and staying in office can be incredibly expensive due to the demands constituents place on their representatives for everything from bus fares and school fees to funeral and wedding expenses. But, there are also benefits:

Editor, "Samoan Parliament told to act on "corrupt practices," Samoa Observer, 20 December 2013.

29 Max Weber, "Politics as a Vocation," in Max Weber: Selections in Translation, ed. Walter. G. Runciman (Cambridge: Cambridge University Press), 1978. 212-225. 
... when you go to a fa'alavelave [traditional ceremonial obligation ] because of out of their own cultural uh sensitivity to their leader, they give you a big a big fine mat, or a carton of eleni [tinned fish], or a carton of pisupo [corned beef], so those are the extras ... In my view that's a straightforward exchange, cultural exchange, because you being there is part of your contribution to the recognition of the work you are doing ... Nothing under the table [laughter]. [HRPP Minister $]^{30}$

Misconduct here is defined in part by its transparency; such exchanges are not secret and therefore most MPs believe they are above-board. Cultural explanations aside, MPs also believe these transactions serve an important economic purpose, especially for cash-poor constituents. This latter view accords with growing recognition in the corruption literature that in certain contexts activities and practices often labelled as "clientelism" are nevertheless "functional" as they substitute for absent state services. ${ }^{31}$ However, while many of these "transactions" are intentionally conspicuous, nearly all MPs concede that this is more difficult for ministers:

I've never been implicated in anything at all. But, I sign contracts. I knew what was going on and attempts that were made either to me or to my associate ministers or to other members of my staff in the ministries. You can read between the lines if you've talked to a contractor. You know what he was going at ... [HRPP Minister $]^{32}$

Here, transactions are made away from the public eye but the misconduct relates to both the person offering the bribe and the minister prepared to take it. Some resist and others get caught. All politicians can recount stories of former colleagues who have been accused of misusing funds. Some are unforgiving whilst others are prepared to extend them the benefit of the doubt. In which case, while aspects of the Faumuina case are unique to Samoa, the broad themes have wider application. Some misconduct cases are clear-cut but, as in this instance, more often they are complex. In part, this is because definitions are ambiguous with some ministers, for example, openly favouring their electorates when allocating projects-they don't see this as misuse of public funds-whilst others consider this an abuse of power. The adversarial nature of democratic politics incentivizes opposition MPs to accuse the government of misconduct-and the Faumuina case is no exception-and yet history tells us that these same MPs tend to find themselves subject to misconduct allegations if and when they gain office.

The imperative to gain and stay in office brings us back to the question about how disputes about conduct should be resolved. Initially, an emergency

30 Author interview, Apia, Samoa, 7 November 2013

31 Mushtaq Khan, "Markets, states and democracy: Patron-client networks and the case for democracy in developing countries," Democratisation 12 no. 5 (2005): 704-724; Walton, "Defining Corruption where the State is Weak: The Case of Papua New Guinea," 6.

32 Author interview, Apia, Samoa, 11 November 2013. 
caucus meeting and a secret ballot saved Faumuina's job. The prime minister stood by his man despite the allegations and disquiet within his party. Some MPs saw this as collective responsibility at work; sacking Faumuina would have reflected poorly on the prime minister who put him in that role. Others believe, as we shall discuss further below, that the prime minister's support was contingent on the politics of leadership succession. In either case, MPs felt that it would be unlikely that Tuilaepa would select Faumuina in his cabinet should he run again in 2016. However, MPs believe that he will regain his seat should he contest the 2016 elections; his constituents are much more forgiving than his colleagues.

The initial controversy surrounding Faumuina's conduct did not dissipate after caucus backed his continued appointment. Rather, it was further inflamed by the leaked release of a report by the chief auditor, which was critical of his conduct. Another caucus meeting followed. In a lengthy response to the Audit Report in parliament on 16 April 2014, Faumuina announced that he intended to resign his portfolio and return to the backbench. ${ }^{33}$ In accepting his decision the prime minister, Tuilaepa, paid tribute to his 14 years of ministerial service. He also took personal responsibility of the now vacant Finance portfolio, a position he had previously held between 1982-2001. ${ }^{34}$ Faumuina did not stay on the backbench for long. By June 2014 he was appointed associate minister for Natural Resources and Environment. ${ }^{35}$ As we shall discuss further below, while this position does not carry the status or responsibility of a cabinet minister, the salary is higher than that of an ordinary backbencher.

In his response to the chief auditor's report Faumuina apologized for any mistakes that he had made but denied any unlawful conduct. He points to the repeated support of the prime minister and the fact that he survived a caucus vote as proof of his innocence; he is not without supporters who believe his accusers are primarily motivated by jealousy—both of his standing within the party but also his position as a possible successor to Tuilaepa-as the initial letter was orchestrated by two MPs who lost their cabinet portfolios after the 2011 election (one of whom is the previous minister of finance). Accusation and counter-accusation continue.

\section{Case study 2: Abuse of Power}

In response to the accusation that politicians have made poor policy choices the obvious defence is that they do not act in a world that is entirely under

\footnotetext{
33 Merita Huch, "Samoa's finance minister resigns: Ruling HRPP bows to growing pressure," Islands Business, May 2014, 28.

34 Lanuola Tupufia, "P.M. takes over Finance - Lautafi new minister in cabinet," Samoa Observer, 27 April 2014.

35 Editor, "Disgraced Samoa Finance Minister Appointed As Associate minister," Samoa Observer, 15 June 2014.
} 
their control. Politics remains, to quote Philp, "stuck in the distinctively human dimension of interpersonal action: it requires the coordination of wills, interests, and political aspirations and imaginations." ${ }^{36}$ This defence, however, is rarely made by politicians as they are elected to bend the world according to their will (or at least that is what they promise during their campaigns). Perversely, on occasions when politicians do take matters into their own hands they open themselves up to the accusation that they have abused their authority. This brings us to our second case which is, first and foremost, about the appropriate use of power.

Initially, there were two versions of this story, the broad parameters of which have been well publicized in the Samoa Observer. ${ }^{37}$ In the first, ${ }^{38}$ Associate Minister Muagututagata Peter Ah Him, the same MP who oversaw the parliamentary inquiry that was damning of Faumuina, was stopped by the police late at night for a traffic violation. He then failed to produce a license or take a breath test properly. The deputy prime minister, Fonotoe, a lawyer by profession, intervened at the scene and was alleged to have told Ah Him to "drive off." Later the incident resurfaced and a police investigation was launched. Both were then charged (Ah Him for making an illegal U-turn and Fonotoe for wilfully obstructing a police officer from executing his/her duty). In the second, outlined in a public letter signed by Fonotoe and published in the Samoa Obsever ${ }^{39}$ Ah Him returned three negative breath tests. Fonotoe was present but did not intervene. Initially no charges were laid but the story was eventually leaked to the media and an inquiry launched.

Ultimately, the court found both MPs guilty. But, we will return to that later as our interest is in what the reaction of MPs to these events can tell us about political conduct. The first point to make is that generally MPs see this issue as different to the Faumuina case:

... a different case altogether because it doesn't involve any funds. That's a case between him and the law because, as I already said, if the police report is true then in the first place he should never had been there, because his relationship with the associate minister is very close ... I mean, he intervened and asked the police what they are doing knowing very well the police doesn't stop anybody unless he's broken the law and so he should know better. [HRPP MP $]^{40}$

There are a whole range of issues tied up in this extract. The first, as alluded to above, is that this case is not specifically about self-interest as in both versions of the story Fonotoe is seeking to help a friend and colleague at no

36 Philp, Political Conduct, 12.

37 Jasmine Netzler, “Samoa Deputy PM, Minister's Trial Begins," Samoa Observer, 5 March 2014.

38 Pai Mulitalo, "Police Probe Allegations Against Samoan Cabinet Ministers," Samoa Observer, 22 October 2013.

39 Editor, "Deputy Prime Minister 'sets the record straight," Samoa Observer, 26 October 2013.

40 Author interview, Apia, Samoa, 6 November 2013. 
direct benefit to himself (albeit Ah Him's support is indirectly important to his leadership ambitions). Rather than personal extravagance, the misconduct here relates to Fonotoe's inability to treat the situation dispassionately. Moreover, as a lawyer, the accusation is that he should have known better; the crime is that he knew he was in the wrong but thought he could get away with it. What makes the act particularly stupid, his colleagues claim, is that in a small island state it is almost impossible to hide anything:

It's a small country ... So you can't hide anything around this place in Samoa ... So I walk away from that kind of rubbish, because I know you can never hide in this country. Never. No matter how long, it will come up. It will come up and it will come back to haunt you. And it will disgrace you forever in this small country, because everybody knows everyone. [HRPP Minister $]^{41}$

In this account, the relativism doesn't relate to culture per se but geography; small countries cannot hide misconduct in the same way that big countries can which gives them a natural advantage in terms of transparency but it also means that citizens are more aware of how their leaders conduct themselves, and, they often do not like what they see. ${ }^{42}$ This dynamic adds to the "high drama" of leadership succession in countries like Samoa, where leaders do not have to work as hard to develop a public profile as they might in larger states, but instead face the need to buttress themselves against criticisms of their conduct from a public that knows their personal history, and that of their family and other associates, all too well.

The Fonotoe case-and despite the fact that there were two MPs involved the deputy prime minister's conduct is treated with more gravity due to his position and the fact that he is a potential leadership candidate-can also be explained from a cultural relativist perspective. In this view, the police initially deferred to Fonotoe in part because he was the deputy prime minister but also because of his matai title. That is, cultural norms trumped legal norms in this instance, with the legal interpretation reapplied in retrospect. Like the example above, where ministers use their portfolio to benefit their constituency, most MPs draw a distinction between cultural and legal norms:

Fa'asamoa [Samoan way of life], you know that's not corruption, it's a way we do things in the families, in the villages, in church, and it carries right up, up to, to government ...

If you benefit yourself personally whatever, then that's corruption as far

${ }^{41}$ Author interview, Apia, Samoa, 11 November 2013.

42 For example see Wouter Veenendaal, "Size and Personalistic Politics: Characteristics of Political Competition in Four Microstates," The Round Table, Ahead-of-print (2013); John Connell, Islands at risk? Environments, Economies and Contemporary Change (Edward Elgar, Cheltenham, 2013); Dag Anckar, "Democratic Standard and Performance in Twelve Pacific Micro-States," Pacific Affairs 75, no. 2 (2002): 207-225. 
as I'm concerned. But you know fa'asamoa, if you help, you know, we have so many things where we can help...

But people when you look from outside, you know, they say that's corruption. [HRPP MP] ${ }^{43}$

In general terms, MPs admit to feeling guilty if they do not intervene on behalf of others. They also describe feeling frustrated with constituents who use elections in particular to take advantage of them by demanding gifts. Getting elected is expensive and many concede that they believe some members seek to recuperate their costs once in office. The misconduct here lies with the people and their insatiable demand for material assistance. As Larmour argues, people are often quick to accuse the powerful of corruption in the Pacific but many also actively participate. On the other hand, MPs agree that if a person gets in trouble with the law they can hide behind culture, just as those who violate cultural norms can hide behind the law, or, in some cases, religion. Norms about conduct, they argue, often contradict. To resolve these matters MPs claim that they try to assess a person's character, and this, more than anything, is where Fonotoe is seen to be at fault.

Fonotoe is seen to be of exemplary character. Time and time again interviewees related how they were surprised at Fonotoe's misjudgementthat is not to say they all thought he was guilty but all conceded he should never have put himself in that position in the first place-which was, for a lawyer of his standing, out of character. One blind spot, they reflected, was his friendship with Ah Him. ${ }^{44}$ The second stain in this instance was that they were both believed to have been drinking. Alcohol consumption is not a crime but MPs stated that they did not think drinking in public was appropriate for a prospective leader. MPs claimed to have consciously altered their social activities once elected to avoid gossip and scandal. Like Faumuina, the issue here is the types of virtues leaders ought to possess rather than legal infringements.

Finally, MPs saw Fonotoe's actions as hypocritical:

And two weeks before that [incident], he was addressing the police who graduated emphasizing what qualities the police should have; like honesty, integrity, and so forth. And yet the police were doing what he was professing ... [HRPP MP $]^{45}$

Taken together, the misconduct here is not related to the legal specificities of the case, but misjudgement; he was in the wrong place at the wrong time

\footnotetext{
43 Author interview, Apia, Samoa, 11 November 2013.

44 He stands charged of fraud, falsifying accounts and theft (Radio New Zealand International, 7 July 2014).

45 Author interview, Apia, Samoa, 7 November 2013.
} 
saying the wrong thing with the wrong people. The underlying question is whether he is fit to become prime minister. Based on this incident, for now, most MPs interviewed, from both parties, believe the answer is no.

Like the Faumuina case, the opposition spent a lot of time talking about process failure. They argued that the process was taking too long, that they should have been stood down whilst being investigated, and that the matter should have been brought before the privileges committee. Unlike Faumuina, the prime minister did not immediately back Fonotoe-interviewees inferred that the two were not on the best of terms, despite being related by marriagebut initially distanced himself from the incident by stating it was a police matter, but reiterating that MPs were not above the law. However, he also refused to stand him down but instead stated that Fonotoe should examine his own conscience over whether it was appropriate for him to resign. Presumably he did, and decided not to. In turn, Fonotoe accused the media of not following the proper process by ignoring the official police statement, which initially cleared him and Ah Him, and instead relied on other sources. ${ }^{46}$

In sentencing Fonotoe, District Court Judge Vaepule Vaemoa Vaai found that the former had been "throwing his weight around in a display of the status of the political office he held." ${ }^{47}$ Ah Him was discharged without conviction but was ordered to pay $\mathrm{T} \$ 250$ to cover court costs. Fonotoe was ordered to pay $\mathrm{T} \$ 200$. He retains his position as deputy prime minister (a larger penalty would have seen him lose his seat in parliament). On hearing his sentence, initially he apologized and declared the matter resolved. Later, he lodged an appeal. ${ }^{48}$ Whatever the outcome, the impact of the incident on Fonotoe's political career is less certain. Most MPs interviewed believe that his leadership credentials are in tatters and that he will not be part of the cabinet should he regain his seat in 2016. Others, including opposition members, are less certain:

People don't really see what's happening to the Deputy Prime Minister. They don't really care. I mean the only ones who care are the educated ones and the opposition and a few others who sort of read the papers ... they are very forgetful and they are very forgiving. If this happened in Australia or New Zealand, that's it, their career will really go down. [Tautua MP] ${ }^{49}$

\section{Case study 3: Conduct Unbecoming}

Case 3 is in many ways the most innocuous of those discussed here but for this reason it is also the most interesting as it has no legal basis but is entirely

46 Pai Mulitalo, "Deputy P.M. downplays Beach Rd. incident," Samoa Observer, 13 October 2013.

47 Editor, "Samoa's Deputy PM Fined, Accused of 'Throwing His Weight Around," Samoa Observer, 16 May 2014.

48 Jasmine Netzler, "Deputy Prime Minister appeals," Samoa Observer, 27 June 2014.

49 Author interview, Apia, Samoa, 8 November 2013. 
bound up in the "high drama" of Samoan politics. In late October 2013 the associate minister for Police and Prisons as well as the Fire and Emergency Services Authority, Lafaitele Patrick Leiataualesa, was suspended for "disorderly behaviour." The specifics of what occurred are far from clear but the account we heard went like this:

They were there to launch the opening of a firehouse station in Savaii, so they had this 'ava ceremony ... the first kava [went to] the minister and then the second one went to the associate minister for police ... But the right thing according to the Samoan custom is for him to get the first kava because it's his ministry, not this other guys' ministry, so he should be given his kava first. So then there's an argument there. $[\text { HRPP MP }]^{50}$

In the argument Lafaitele allegedly abused an official and was subsequently suspended for twelve months, following a caucus meeting, but the process by which the decision was made is not public knowledge as MPs, including the prime minister, refused to disclose how the decision was reached. It appears, however, that the prime minister made the decision unilaterally if we believe the quote attributed to the HRPP whip, Tolofuaivalelei Falemoe Lei'ataua, in the Samoa Observer, in which he stated: "Only the Prime Minister knows what happened because the decision was made by him." ${ }^{51}$ Aside from public embarrassment, the decision had important financial implications for Lafaitele as associate ministers (and all HRPP members are either associate ministers or ministers) receive greater privileges than ordinary members.$^{52}$ As discussed, this matters in Samoa, where MPs are expected to provide constituents with cash and other forms of largesse.

The first question arising from this case is whether the punishment fits the crime. HRPP members are divided on this. Some believe that he is the luckiest of the three to still be in the party. From the outside, this admission is astounding given the gravity of the other two cases. However, as one MP argued, this is not the first indiscretion by Lafaitele..$^{53}$ In this version, the decision to sack him is based on a culmination of offences rather than an isolated incident; the belief is that Lafaitele's character is at fault here. As we have seen in the previous two cases, character matters in Samoa where adultery, for example, is legal grounds for an MP to be dismissed. Walton refers to this view of corruption as moral decay, although, as we saw with Faumuina, these norms can extend to vices like hubris, for instance. ${ }^{54}$

50 Author interview, Apia, Samoa, 6 November 2013.

51 Jasmine Netzler, “Only the OM Can..." Samoa Observer, 6 November 2013.

52 A move designed to keep the HRPP's parliamentary numbers intact, see Iati, "Samoa's Price for 25 Years of Political Stability."

53 Author interview, Apia, Samoa, 7 November 2013.

54 Walton, "Defining Corruption where the State is Weak: The Case of Papua New Guinea," 6. 
Politicians talk about changing their dress and socialization habits once becoming MPs on the grounds that they believe they are expected to hold themselves to a higher standard. They argue that any MP who is convicted of any offence, no matter how minor, should automatically lose their seat. Others contend that parties should screen out potential candidates who have even the slightest hint of misconduct in their past. Conversely, like all democracies, publics revel in scandals, particularly those that have a whiff of hypocrisy. Some see gross hypocrisy at work here-surely the prime minister has sworn at an official before? Certainly other ministers have also? So why haven't they been suspended?

... we believe it never necessitated the ... suspension. But I believe the Prime Minister was trying to give a message to everybody that you need to go by the rules. Once you step out of line then this is your -this is your end. So he loses all his salary [and] he loses his vehicle...

... it is only for foul language. Nothing bad it. It's common. I mean, if you're frustrated with something that has been done, according to Samoan culture, that it's not right, you'd be frustrated ...

We believe that his anger was motivated by something right, not just out of the blue ... We're all, we're not angels. And then it was only a minor incident and yet he suspended that guy. [HRPP MP $]^{55}$

In this view, Lafaitele is an unfortunate scapegoat whose indiscretion is being used by the prime minister to send a message to his party—stay in line or face the consequences-and to the public-I am in control and am not afraid to deal with those who misbehave. From this perspective, Lafaitele's main crime is that he is expendable; unlike Faumuina and Fonotoe, he doesn't have enough support within the party that his suspension would cause further division. Ultimately, the issue here is trust. Some MPs trust the prime minister's leadership, they believe he has access to all of the information and therefore is best placed to make a decision. They may not entirely understand the specifics of the case, but they believe the prime minister does. Critics of the prime minister disagree. They believe the proper process would have been to consult the party before suspending him, as in the Faumuina case.

But what would such a process reveal? Caucus can only hear from the concerned parties. When making up their minds in such instances MPs claim they talk to each other and read the newspaper. There isn't, they concede, any capacity for caucus to initiate a substantive investigation. They make their judgements based on a combination of whom they trust and their own personal political strategies. For politicians, electoral politics is trial by popularity and caucus is only marginally different:

55 Author interview, Apia, Samoa, 6 November 2013. 
[Be]cause if you take it to caucus, you might have some friends there [laughs]. I mean people there are the-I mean, you know, it's very difficult to make up your mind because you are not a judge. How can you judge if you don't know all the sides? It's just hearsay, you rely on hearsay. So it's that thing. [HRPP Minister $]^{56}$

Five months after his suspension, Lafaitele was reinstated as an associate minister. ${ }^{57}$ The cabinet minister he will be assisting is none other than the new minister of Finance, Tuilaepa.

\section{Political Conduct, High Drama and the Politics of Succession}

I think it all started when we heard through the grape vine that the P.M. was going to step down the next election ... I think that is when everybody started to see who is going to take over the leadership and that created friction with the Party... (Tautua MP Lealailepule Rimoni Aiafi) ${ }^{58}$

The regular rotation of leadership is a key feature of democratic government and yet, as we have seen, succession can flame political scandal and accusations of corruption. For those who favour independent and objective methods to sanction conduct-anti-corruption commissions and the likethe "high drama" of Samoan politics, as described here, is inherently compromised as all three cases are inextricably bound up in the politics of succession. Opposition MPs, many of whom are former HRPP members, see the answer to the succession question as a change of government. This view works in the short-term but at some point all parties face the need to change leadership. For those who believe the HRPP is best placed to govern Samoa the question of succession is more complex. One MP, who is a critic of Faumuina, summed up the situation like this:

Faumuina is totally not on our list. Fonotoe is now involved in some minor issues ... If it's proven, then [he's] totally out of the list as well. So we might as well get him [Tuilaepa] back and continue to do his non-democratic ... one-man band. [HRPP MP] ${ }^{59}$

Here again, the misconduct relates to process: the prime minister is accused of not paying heed to the views of his members. MPs argue that he used to be more consultative but that the stability brought about by measures to secure numbers in parliament ${ }^{60}$ has changed his style; the prime minister has made himself indispensable.

\footnotetext{
Author interview, Apia, Samoa, 11 November 2013.

Editor, "Lafaitele off to Jakarta," Samoa Observer, 12 June 2014.

Cited in the Samoa Observer, 26 May 2014.

Author interview, Apia, Samoa, 6 November 2013.

60 Iati, "Samoa's Price for 25 Years of Political Stability."
} 
Most MPs, both government and opposition, felt that Tuilaepa was the only option as prime minister. Despite being publically critical of the prime minister and the HRPP in the newspaper, one prominent journalist conceded that he remains the most upstanding MP:

\begin{abstract}
Now what I'm going to say will surprise you. I think the Prime Minister's great, despite everything, we [have] never be[en] able to pin him down for one particular incident related to corruption where he's abused public property ... the guy is just squeaky clean ... or he's just smart [Laughter]. Seriously, I mean, I cannot remember, the guy has mainly been criticized for people around him, but never really about him directly ... I cannot see this country being run by anybody else but the Prime Minister. As critical as I am in this government, I cannot. [Journalist]. ${ }^{61}$
\end{abstract}

It is a view that easily lends itself to a consequentialist defence of all measures required to keep him in that position. From this perspective, when dealing with his colleague's indiscretions, the prime minister has to "suck it up and hope they don't do it again." [HRPP Minister ${ }^{62}$

In 2011 most commentators and HRPP members felt that Tuilaepa would stand down before the 2016 election. By the end of 2013, this view has almost entirely reversed. Given the alleged indiscretions of his two most obvious successors, there appears to be no credible alternative candidate and so, both government and opposition members expect that he will go around again. Time will tell. We tried to interview Tuilaepa as part of our research but he was off island and subsequent attempts to organize a telephone interview have failed to eventuate. In any case, whatever happens, these three incidents offer lessons of more general relevance.

\title{
Conclusion
}

In seeking to understand how politicians in Samoa define corruption and misconduct, we found that, contrary to popular belief and the absence of anti-corruption institutions, politicians have standards of conduct that they seek to adhere to and uphold. ${ }^{63}$ But, in all cases, these standards, be they legally or social constructed, also function as rhetorical tools used to publicly defend, justify or condemn actions. ${ }^{64}$ The literature on corruption tends to follow organizations like Transparency International and define it as the "use of public office for private gain" and the "abuse of power." As we saw, these traditions are also apparent in Samoa. However, following the call for researchers interested in corruption and misconduct to broaden how they

61 Author interview, Apia, Samoa, 5 November 2013.

62 Author interview, Apia, Samoa, 7 November 2013.

63 Corbett, "Politicians and Professionalization in the Pacific Islands: Revisiting Self-Regulation?"

64 Frederick Bailey, Treasons, Stratagems, and Spoils (Cambridge Massachusetts: Westview Press 2001), 115 . 
understand the term and carry out research on it, we have also shown how, despite having no legal basis, in the "high drama" of Samoan politics, character and accusations of moral decay can demand higher standards of conduct than the law. In part, as outlined in case study 2 , this can be attributed to the nature of politics in small states, where the reduced social distance between ruler and ruled means that the public can ascertain intimate details of specific events that may not be available to citizens of larger states, leading to a natural level of heightened transparency. However, given that scale is only one of many interpretations given by politicians to make sense of these cases, our findings also support Philp's more general conclusion that all regulation, be it legally enshrined or socially enforced, is a "fragile achievement" that remains open-ended and evolving. ${ }^{65}$

Our contribution builds on the work of scholars interested in broadening definitions of corruption. Not only do our cases add the usually ignored views and perceptions of politicians but by focussing on leadership succession we also show how political actors simultaneously manufacture and make sense of political conduct amidst the "high drama" of political scandal. Rather than deterministic or path-dependent institutions or discourses- "legal rational" versus "tradition" or "culture," for example-by employing the concept of "situated agency" we linked the views of individual politicians about what constitutes corruption with specific instances where they or their colleagues faced public scrutiny about their conduct. We found a dynamic and open-ended conversation in which interpretations of misconduct and corruption are constantly being (re)constructed. In doing so we showed that meanings are not only divergent and country specific, in the way that some scholars of corruption have been at pains to describe, but that they also interact in a contingent, iterative and dramatic fashion with the political setting (particularly leadership succession in this instance) in which they are situated. The lesson that emerges from our portrayal is that questions about conduct are always grounded in the cut and thrust of everyday politics as actors compete to define the situation at hand. What we have done, using these three cases as examples, is show how.

Griffith University, Nathan Campus, Brisbane, Australia

The Australia National University, Canberra, Australia, July 2014

65 Philp, Political Conduct, 5. 